\title{
Brought more than twice: the complex introduction history of the red swamp crayfish into Europe
}

\author{
Francisco J. Oficialdegui ${ }^{1, *}$, Marta I. Sánchez ${ }^{2}$, Christophe Lejeusne ${ }^{3}$, \\ Nic Pacini ${ }^{4,5,6}$ and Miguel Clavero ${ }^{7}$ \\ ${ }^{1}$ Department of Wetland Ecology, Estación Biológica de Doñana (EBD-CSIC), Seville, Spain \\ ${ }^{2}$ Department of Plant Biology and Ecology, Faculty of Biology, University of Seville, Seville, Spain \\ ${ }^{3}$ Institut Méditerranéen de Biodiversité et d'Écologie Marine et Continentale (IMBE), UMR 7263, Aix Marseille Université, CNRS, \\ IRD, Avignon Université, Station Marine d'Endoume, Marseille, France \\ ${ }^{4}$ Department of Environmental and Chemical Engineering, University of Calabria, Calabria, Italy \\ ${ }^{5}$ School of Geography, Geology and the Environment, University of Leicester, Leicester, UK \\ ${ }^{6}$ Department of Invertebrate Zoology, National Museums of Kenya, Nairobi, Kenya \\ ${ }^{7}$ Department of Conservation Biology, Estación Biológica de Doñana (EBD-CSIC), Seville, Spain
}

Received: 4 July 2019 / Accepted: 29 October 2019

\begin{abstract}
One of the biggest challenges in understanding and managing biological invasions is the identification of the routes of introduction. This information is often incomplete because of unnoticed, unreported and, sometimes, illegal translocations. Reports on the introduction of the red swamp crayfish (Procambarus clarkii) into Europe describe that it was introduced for the first time to southern Spain (1973 and 1974) from Louisiana; from there, it rapidly spread throughout several European countries. While other importation events and pathways of introduction have been suggested in the literature, there is no evidence that these led to wild populations in Europe. Our present study suggests two additional introduction routes into Europe from non-European areas where the red swamp crayfish had previously been reported. By using mtDNA, we found a shared haplotype between the Lake Naivasha in Kenya and Western Europe, as well as another between either western United States or Asia, and Malta. These findings support historical reports found in the literature for the former case and also point towards pet trade as driver of new introductions for the latter, thus highlighting the complex introduction history of the red swamp crayfish populations in Europe.
\end{abstract}

Keywords: Invasion route / Lake Naivasha / mitochondrial DNA / pet trade / Procambarus clarkii

Résumé - Apportées plus de deux fois: I'histoire complexe de l'introduction de l'écrevisse de Louisiane en Europe. L'un des plus grands défis à relever pour comprendre et gérer les invasions biologiques est l'identification des voies d'introduction. Ces informations sont souvent incomplètes en raison de transferts inaperçus, non déclarés et, parfois, illégaux. Les rapports sur l'introduction de l'écrevisse de Louisiane (Procambarus clarkii) en Europe décrivent qu'elle a été introduite pour la première fois dans le sud de l'Espagne (1973 et 1974) à partir de la Louisiane; de là, elle s'est rapidement répandue dans plusieurs pays européens. Bien que d'autres événements d'importation et voies d'introduction aient été suggérés dans la littérature, rien n'indique qu'ils aient conduit à des populations sauvages en Europe. Notre présente étude suggère deux voies d'introduction supplémentaires en Europe à partir de zones non européennes où l'écrevisse de Louisiane avait déjà été signalée. En utilisant l'ADNmt, nous avons trouvé un haplotype partagé entre le lac Naivasha au Kenya et l'Europe occidentale, ainsi qu'un autre entre l'ouest des États-Unis ou l'Asie et Malte. Ces résultats corroborent les rapports historiques que l'on trouve dans la littérature sur le premier cas et indiquent également que le commerce d'animaux de compagnie est le moteur de nouvelles introductions

\footnotetext{
*Corresponding author: oficialdegui@ebd.csic.es
} 
pour le second, mettant ainsi en lumière l'histoire complexe de l'introduction des populations d'écrevisses de Louisiane en Europe.

Mots-clés : Origine d'introduction / lac Naivasha / ADN mitochondrial / commerce des animaux de compagnie / Procambarus clarkii

\section{Introduction}

Identifying the routes of introduction is important to understand, predict and manage biological invasions (Estoup and Guillemaud, 2010; Cristescu, 2015). This identification may be hampered because introduction events are often unreported, incompletely reported (e.g. information on the origin of introduced populations is lacking) or reported in inaccessible sources (e.g. administrative documents). Molecular tools offer opportunities to reconstruct unreported invasion routes by linking the wild established populations with their potential sources as well as comparing the genetic profiles of native and introduced populations (Estoup and Guillemaud, 2010; Fitzpatrick et al., 2012).

The red swamp crayfish Procambarus clarkii (Girard 1852), native to southern U.S.A. and northeastern Mexico, has been intentionally introduced in at least 40 countries and all continents except Australia and Antarctica (Oficialdegui et al., in review) to be bred and consumed as food (Hobbs et al., 1989) or to be sold as an aquarium species (Chucholl, 2013; Faulkes, 2015). It has become the most cosmopolitan freshwater crayfish in the world, as well as one of the most ecologically destructive invaders (Gherardi and Acquistapace, 2007). It was first brought to Europe from Louisiana (U.S.A.) in 1973, when it was introduced to the middle Guadiana Basin, Badajoz province in Spain, and in 1974, when a new and independent introduction took place in the rice fields of the lower Guadalquivir, Seville province (Habsburgo-Lorena, 1978). It has been generally thought that the European range of the red swamp crayfish results from the expansion of these two founder populations, driven by multiple (an unknown number, but arguably thousands) uncontrolled translocations (for example in the Iberian Peninsula, Gutiérrez-Yurrita et al., 1999). This assumption seems to be supported by the high haplotype diversity of invasive populations in southwestern Spain, and by such diversity progressively decreases as one moves towards the North, as recently reported by Oficialdegui et al. (2019). However, other introduction events from different sources cannot be ruled out in some European countries (Patoka et al., 2014 and references therein; Weiperth et al., 2019). Actually, Oficialdegui et al. (2019) found a COI haplotype across Western Europe (NW France, northern Italy, Belgium, the Netherlands and United Kingdom) that was not detected either detected in the Iberian Peninsula, or in southern France or southern Italy (Oficialdegui et al., 2019). This finding was interpreted as the probable result of an unreported introduction into Europe, in addition to those that occurred in Spain in the 1970s. The possibility of other plausible routes of introduction into Europe has been suggested in the literature, but never explicitly supported. For example, Barbaresi et al. (2007) proposed that red swamp crayfish could have been brought to Italy from China, while Laurent et al. (1991) and Goddard and Hogger (1986) suggested that it could have been introduced to France and to the United Kingdom from Kenya for human consumption.
Here, we investigate whether the invasion of Europe by the red swamp crayfish may have involved other different routes of invasion from the initial inoculums from Louisiana to SW Spain in the 1970s. We focussed specifically on possible routes originating from Africa, western U.S.A. and/or Asia. To that aim, we (1) analysed the mitochondrial DNA (mtDNA) of red swamp crayfish from Lake Naivasha in Kenya and (2) compiled and re-analysed recently published sequences from red swamp crayfish populations, both in Europe and elsewhere.

\section{Material and methods}

We collected a total of nine red swamp crayfish from Lake Naivasha (Kamere Landing Beach, $0^{\circ} 48.88^{\prime}$ S; 36 $19.46^{\prime}$ E), Kenya. Muscle tissue was extracted on site and individually preserved in $96 \%$ ethanol until subsequent genetic analyses. Extraction of mtDNA, the use of cytochrome oxidase 1 (COI) primers, sequencing protocols as well as the procedure with the genetic analyses and bioinformatics were performed as in Oficialdegui et al. (2019). Briefly, genomic DNA was extracted from muscle tissue using a modified DNA saltextraction protocol and proteinase $\mathrm{K}$; a fragment of the mitochondrial gene coding for the cytochrome c oxidase subunit I gene was amplified using the primers LCO1490 and HCO2198 and PCR amplifications were carried out in a $20-\mu 1$ reaction volume. In addition, we also re-assessed 10 sequences $(559$ bp; Genbank Accession number: MF170527-36) recently published by Vella et al. (2017), referring to a population established in Malta, as well as the 65 haplotypes (608bp) reported by Oficialdegui et al. (2019). The 84 sequences in total were then analysed. After alignment and trimming of all sequences (Kenyan and Maltese), a matrix of 559 bp was obtained.

\section{Results}

The nine red swamp crayfish specimens from Kenya shared a common haplotype, while a different haplotype was common to the 10 specimens from Malta reported by Vella et al. (2017). The Kenyan haplotype was identical to the one found in Western Europe but was not present anywhere else (Hap_11, GenBank: MK026681 in Oficialdegui et al., 2019). Because of the trimming of sequences, the Maltese haplotype corresponds to two haplotypes (Hap_28, MK026698 and Hap_41, MK026711; in Oficialdegui et al., 2019) occurring mainly in Asia, with Hap_28 being much more widespread than Hap 41. Interestingly, Hap 28 is also present in western North America, where the red swamp crayfish is also an invasive species (Fig. 1; Oficialdegui et al., 2019). None of the two possible haplotypes found in Malta have been found in the red swamp crayfish native area. 


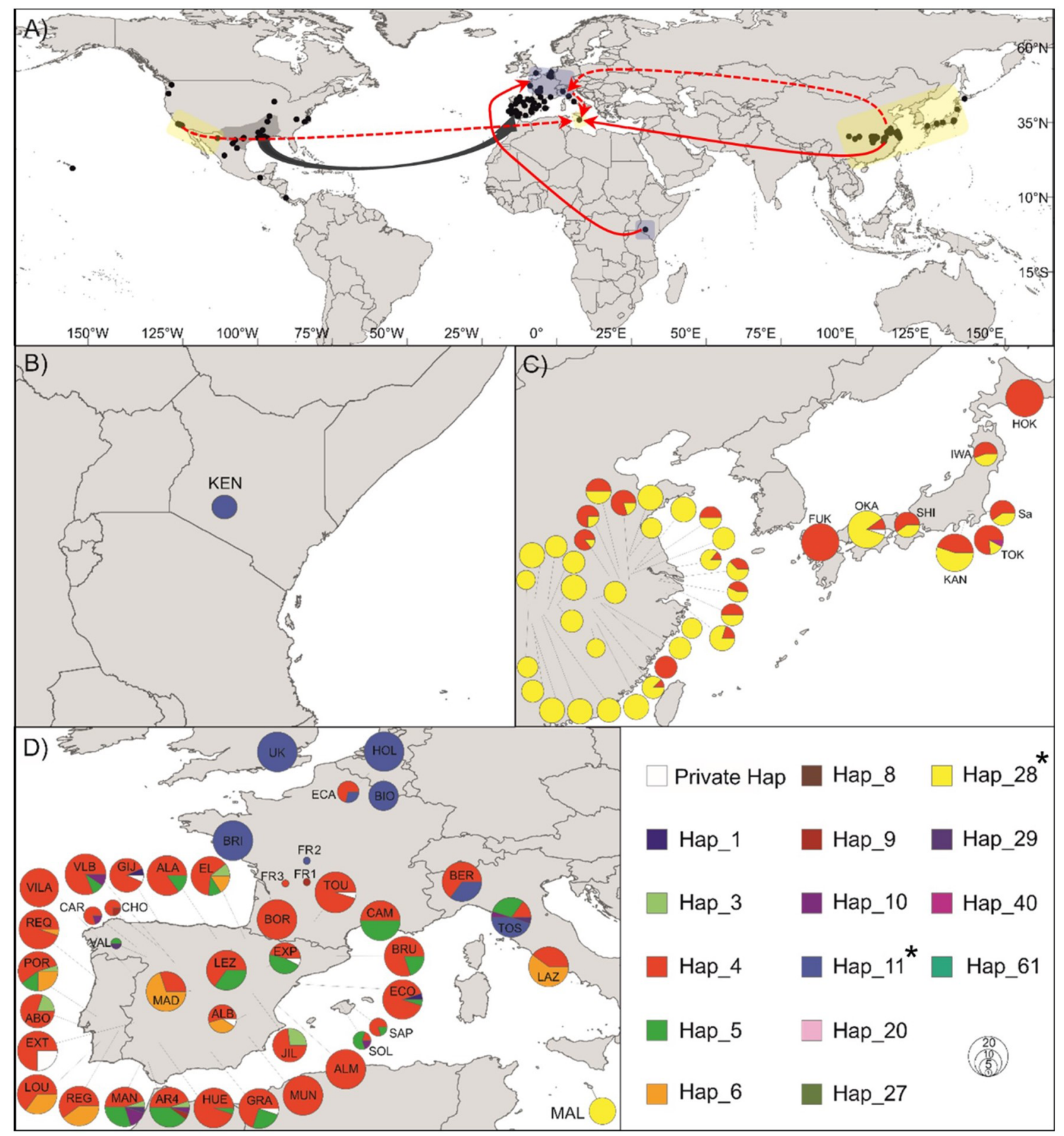

Fig. 1. Haplotype distribution and plausible invasion routes of the red swamp crayfish from non-European areas into Europe (modified from Fig. 1 in Oficialdegui et al., 2019). (A) Introduction routes are depicted by continuous (plausible routes) and discontinuous red arrows (hypothetical route), the dark grey arrow indicates the known introductions from Louisiana in 1970s, and the yellow and blue shading depict the area where Hap_28 and Hap_11 are distributed; (B) Hap_11, in Kenyan population; (C) Hap_28, main haplotype in Asian distribution and Hap_41 is the private haplotype in OKA population; (D) European haplotype distribution with presence of Hap_11 and Hap_28 in Malta (more likely, see Sect. 4). * Indicates shared haplotypes between non-European and European areas showed in this study.

\section{Discussion}

The findings of shared haplotypes between Kenya and Western Europe, as well as between Asia (or western U.S.A.) and Malta, show that the two well-documented 1970s' introductions into Spain were not the only ones resulting in wild introduced populations in Europe. Indeed, both haplotypes were not found in the exhaustive sampling carried out in southern Spain, suggesting that other sources (e.g., Africa) and other pathways of introduction (e.g., pet trade) may have 
happened, especially for the northern European distribution of the red swamp crayfish. We thus illustrate that the invasion process of the red swamp crayfish in Europe, and plausibly elsewhere, can be more complex than generally assumed.

\subsection{From Africa to Europe}

The red swamp crayfish was introduced from the U.S.A. to several African countries, firstly to Uganda and subsequently, Kenya, Zambia, Sudan, South Africa (Huner, 1977; Mikkola, 1996), Egypt (Hamdi, 1994), and recently to Morocco allegedly from Spain (El Qoraychy et al., 2015). The introduction into Lake Naivasha (Kenya) was particularly successful and a large population developed in the lake from only 300 individuals introduced in 1966 from a previously invasive population in Uganda (Oluoch, 1990). The successive population bottlenecks accumulated by the Lake Naivasha population (several introduction events, at least some of them involving few individuals) could explain why only one haplotype was found in it, though our low sampling size ( 9 individuals) cannot be excluded. The low genetic diversity was not an impediment for the success of the red swamp crayfish in Lake Naivasha, where it rapidly reached extremely high densities (Harper et al., 2002). Commercial exploitation was initiated in the early 1970s, with exports starting from 1975 until sudden stopping in 1983 (Harper et al., 2002), when the importation of live crayfish was banned by most European countries (Laurent et al., 1991). According to Laurent et al. (1991), tonnes of live crayfish were exported to France from both Kenya and Spain between 1975 and 1983. Goddard and Hogger (1986) reported that live red swamp crayfish from Kenya were also imported into England for culture trials and wholesale fish market, although they thought that there were no wild populations established there by the mid-1980s. Our results suggest that imports originating from Kenya could have given rise to some self-sustaining populations in either France or England or both, and that these initial nuclei would have spread across Western Europe.

\subsection{From Asia to Europe}

The presence of one haplotype in Malta shared by several red swamp crayfish populations in Asia and western U.S.A. (Oficialdegui et al., 2019) suggests another unreported introduction route into Europe. Barbaresi et al. (2007) suggested that red swamp crayfish could have been imported to Italy (specifically to Tuscany) from Asia and released into the wild by the numerous Chinese community settled near Florence. If such introduction had taken place, Italy would be a good candidate as the origin of the red swamp crayfish introduced to Malta, acting as a stepping-stone between China and the final destination. However, Oficialdegui et al. (2019) found neither the Maltese haplotype nor any other Asian haplotype in Italy, despite of having described high haplotype diversity in the country, especially in Tuscany. This pattern does not support the stepping-stone role of Italy, but it does not rule it out. In this sense, further analysis for the genetic variability of southern Italian populations, especially from Sicily, where the species is known to be present since at least 2002 (Deidun et al., 2018), would be needed.

\subsection{Pathways of introduction}

In the United States, crayfish movements mediated by biological supply companies are known of having generated self-sustaining wild populations (Larson and Olden, 2008). Several biological supply companies are located in western U. S.A. (California), where the Maltese haplotype is known to be present, and they have been suggested to be a potential source of the red swamp crayfish within U.S.A. (Oficialdegui et al., 2019). Hence, live red swamp crayfish specimens could be readily obtained and transported overseas, as it long occurred with scientific studies which obtained live specimens for their research in the past (Oficialdegui et al., in review). However, on the basis of our results here, the genetic variability of the red swamp crayfish recently reported by Oficialdegui et al. (2019) and the occurrence of the red swamp crayfish together to other non-native decapods (Deidun et al., 2018), we propose that the Maltese population could have originated from releases of live specimens as result of pet trade from Asian countries rather than a biological supply companies from U.S.A (see Patoka et al., 2014).

The Asian origin of the red swamp crayfish found in Malta could be also linked to the long-lasting diplomatic relationships between China and Malta (dating back to 1972) including the 2014 Memorandum of Understanding, which facilitates commercial, cultural and scientific exchanges (Camilleri, 2019). One of the main cooperation lines signalled in that agreement was aquaculture, a relevance that resulted in the promotion of a Malta-China Joint Research Laboratory in Aquaculture (Parliament of Malta, 2016). However, the red swamp crayfish has not been the focus of the aquaculture development in Malta, first because most aquaculture programmes performed on the island are dedicated to marine species and second because such an aquaculture initiative would have been vetoed by the European Union based on the well-documented severe impacts of the red swamp crayfish in Europe (Souty-Grosset et al., 2016; Nentwig et al., 2018).

Pet trade is however a more likely pathway for the red swamp crayfish introduction into Malta. Central European countries such as Germany, Hungary, and Czech Republic are importation gateways for many aquarium species, which are then distributed to other European countries (Kalous et al., 2015; Patoka et al., 2015; Weiperth et al., 2019). In fact, it has already been suggested that several red swamp crayfish populations in Central Europe could have originated as consequence of aquarium releases (see Chucholl, 2013), though there are no genetic evidences. The very recent origin of the Maltese population, first detected in 2016 (Vella et al., 2017), and its occurrence together with other invasive decapods widely used by aquarists (e.g., Procambarus virginalis or Atyopsis moluccensis) (Deidun et al., 2018), suggest that pet trade may have facilitated the arrival of the invasive crayfish to Malta. The identical genetic identity of this Maltese population to haplotypes found in China (Oficialdegui et al., 2019) and that live crayfish specimens imported into Europe are originated by pet trade from southeast Asian countries (Chucholl, 2013; Patoka et al., 2014) suggest an Asian origin. In fact, we cannot discard that this Maltese population was a possible introduction from European introduction hubs (countries above mentioned). Understanding 
the genetic identity of potential sources originated of pet trade is relevant for preventing new introductions and controlling the actual commercial routes that are being established from Asia to occidental countries (Liu et al., 2019).

Our findings have implications for the understanding of the complex invasion by the red swamp crayfish, one of the most harmful invasive species in Europe (Nentwig et al., 2018). While our results seem to support the introduction from Africa to Western Europe thus corroborating the reports previously described in literature, pet trade cannot be discarded due to the strong influence of the hubs for invaders in Central Europe, similarly to the occurrence of wild populations in Malta. This study provides evidences of that the invasion of red swamp crayfish expanding across Europe from introductions in Southwest Spain from Louisiana is a simplification of a considerably more complex invasion process where introductions from other sources have taken place. Additionally, this study discusses the crucial role that pet trade may have in recent introductions within Europe. In order to establish direct evidences of pet trade and wild invasive populations, further research should focus on studying the genetic link between aquaculture hubs, wholesalers and pet shops from southeastern Asia as well as European hubs for invaders with wild established populations.

Acknowledgements. We thank the Laboratorio de SIG y Teledetección (LAST-EBD) at Estación Biológica de Doñana (CSIC) for providing logistical support; and one anonymous reviewer who provided very helpful comments on the manuscript. F.J.O. was supported by an Andalusian Government grant. This study was funded by the Andalusian Government (RNM-936) and PICS (PIC2015FR4 and PICS07360).

\section{References}

Barbaresi S, Gherardi F, Mengoni A, Souty-Grosset C. 2007. Genetics and invasion biology in fresh waters: a pilot study of Procambarus clarkii in Europe. In Biological invaders in inland waters: Profiles, distribution, and threats. Dordrecht: Springer, pp. 381-400.

Camilleri J. 2019. Malta's commerce agreement with China. The official business portal of the Malta Chamber of Commerce, Enterprise and Industry. Available at: https://www.maltachamber. org.mt/en/blogs/155 (accessed February 15th 2019).

Chucholl C. 2013. Invaders for sale: trade and determinants of introduction of ornamental freshwater crayfish. Biol Invasions 15: $125-141$

Cristescu ME. 2015. Genetic reconstructions of invasion history. Mol Ecol 24: 2212-2225.

Deidun A, Sciberras A, Formosa J, et al. 2018. Invasion by nonindigenous freshwater decapods of Malta and Sicily, central Mediterranean Sea. J Crustacean Biol 38: 748-753.

El Qoraychy I, Fekhaoui M, El Abidi A, Yahyaoui A. 2015. Heavy metals in Procambarus clarkii of Rharb Region in Morocco and Its Safety for Human consumption. J Environ Sci Toxicol Food Technol 9: 38-43.

Estoup A, Guillemaud T. 2010. Reconstructing routes of invasion using genetic data: why, how and so what? Mol Ecol 19: $4113-4130$.
Faulkes Z. 2015. The global trade in crayfish as pets. Crustacean Res 44: 75-92.

Fitzpatrick BM, Fordyce JA, Niemiller ML, Reynolds RG. 2012. What can DNA tell us about biological invasions? Biol Invasions 14: 245-253.

Gherardi F, Acquistapace P. 2007. Invasive crayfish in Europe: the impact of Procambarus clarkii on the littoral community of a Mediterranean lake. Freshw Biol 52: 1249-1259.

Goddard JS, Hogger JB. 1986. The current status and distribution of freshwater crayfish in Britain. Field Stud 6: 383-396.

Gutiérrez-Yurrita PJ, Martinez JM, Ilhéu M, Bravo-Utrera MA, Bernardo JM, Montes C. 1999. The status of crayfish populations in Spain and Portugal. Crustacean Issues 11: 161-192.

Habsburgo-Lorena AS. 1978. Present situation of exotic species of crayfish introduced into Spanish continental waters. Freshw Crayfish 4: 175-184.

Hamdi SAH. 1994. Studies on the red swamp crawfish Procambarus clarkii (Girard, 1852) (Decapoda: Camaridae) in the River Nile, Egypt. M. Sc.Thesis, Fac. Sci., Cairo Univ., $136 \mathrm{pp}$.

Harper DM, Smart AC, Coley S, et al. 2002. Distribution and abundance of the Louisiana red swamp crayfish Procambarus clarkii Girard at Lake Naivasha, Kenya between 1987 and 1999. Hydrobiology 488: 143-151.

Hobbs H, Jass J, Huner JA. 1989. A review of global crayfish introductions with particular emphasis on two North American species. Crustaceana 56: 299-316.

Huner JV. 1977. Introductions of the Louisiana Red Swamp Crayfish, Procambarus clarkii (Girard); an update. Freshw Crayfish 3: 193-202.

Kalous L, Patoka J, Kopecký O. 2015. European hub for invaders: Risk assessment of freshwater ornamental fish exported from the Czech Republic. Acta Ichthyol Piscat 45: 239-245.

Larson ER, Olden JD. 2008. Do schools and golf courses represent emerging pathways for crayfish invasions. Aquat Invasions 3: 465-468.

Laurent PJ, Leloirn H, Neveu A. 1991. Remarques sur l'acclimatation en France de Procambarus clarkii (Decapoda Cambaridae). Publ Soc Linn Lyon 60: 166-173.

Liu X, Blackburn TM, Song T, Li X, Huang C, Li Y. 2019. Risks of biological invasion on the belt and road. Curr Biol 29: 499-505.

Mikkola H. 1996. Alien freshwater crustacean and indigenous mollusc species with aquaculture potential in Eastern and Southern Africa. Southern Afr J Aquat Sci 22: 90-99.

Nentwig W, Bacher S, Kumschick S, Pyšek P, Vilà M. 2018. More than "100 worst" alien species in Europe. Biol Invasions 20: $1611-1621$

Oficialdegui FJ, Clavero M, Sanchez MI, et al. 2019. Unravelling the global invasion routes of a worldwide invader, the red swamp crayfish (Procambarus clarkii). Freshw Biol 64: 1382-1400.

Oficialdegui FJ, Sanchez MI, Clavero M. in review. One century away from home: how the red swamp crayfish took over the world.

Oluoch AO. 1990. Breeding biology of the Louisiana red swamp crayfish Procambarus clarkii Girard in Lake Naivasha, Kenya. Hydrobiology 208: 85-92.

Parliament of Malta. 2016. Annual Report and Financial Statements 2015. Available at: https://www.parlament.mt/media/88319/08227. pdf (accessed February 15th 2019) 
Patoka J, Kalous L, Kopecký O. 2014. Risk assessment of the crayfish pet trade based on data from the Czech Republic. Biol Invasions 16: 2489-2494.

Patoka J, Kalous L, Kopecký O. 2015. Imports of ornamental crayfish: the first decade from the Czech Republic's perspective. Knowl Manag Aquat Ecosyst 416: 04.

Souty-Grosset C, Anastacio PM, Aquiloni L, et al. 2016. The red swamp crayfish Procambarus clarkii in Europe: impacts on aquatic ecosystems and human well-being. Limnologica 58: 78-93.
Vella N, Vella A, Mifsud CM. 2017. First Scientific Records of the Invasive Red Swamp Crayfish, Procambarus clarkii (Girard, 1852) (Crustacea: Cambaridae) in Malta, a Threat to Fragile Freshwater Habitats. Nat Eng Sci 2: $58-66$.

Weiperth A, Gál B, Kuř́ková P, Langrová I, Kouba A. 2019. Risk assessment of pet-traded decapod crustaceans in Hungary with evidence of Cherax quadricarinatus (von Martens, 1868) in the wild. North-Western J. Zool. 15: 42-47.

Cite this article as: Oficialdegui FJ, Sánchez MI, Lejeusne C, Pacini N, Clavero M. 2020. Brought more than twice: the complex introduction history of the red swamp crayfish into Europe. Knowl. Manag. Aquat. Ecosyst., 421, 2. 